\title{
Isolation and characterization of lytic bacteriophages as an alternative to prevent pseudomonas SPP in poultry industry
}

\begin{abstract}
The Pseudomonas genus is a big problem mainly for the poultry food industry. The shelf life of chicken carcasses stored under refrigeration is limited by the appearance of undesirable odors and sliminess surface generated primarily by Gram negative bacteria. Due to the subsequent emergence of resistant bacteria, is necessary proving new alternatives as guaranty the microbiological quality of foods and human health. Bacteriophages or phages are viruses of bacteria that use resources of bacteria for their replication and killing bacteria "naturally", showing them as a potential tool for bacteria biocontrol in food industry. In this study, 11 bacteriophages were isolated from the exudate product of defrost of chicken carcasses using as host strains Pseudomonas aeruginosa (ATCC 25619) and Pseudomonas fluorescens (ATCC 13525). This study also aimed at the purification, quantification and morphological and molecular characterization of phages (RFLP). Bacteriophage can be found in all types of environments, it was possible to perform isolation and purification and achieve concentrations of $1011 \mathrm{PFU} / \mathrm{mL}$, which demonstrated a broad spectrum of action on different bacteria of the family Enterobacteriaceae. Bacteriophages were classified as belonging to the order of Caudovirales and families Podoviridae and Myoviridae. Bacteriophages showed similar morphology, but some showed different genetic profiles.
\end{abstract}

Keywords: lytic bacteriophages, pseudomonas, chicken carcasses, isolation, biocontrol, characterization
Volume I Issue 3 - 2015

\author{
Maryoris E Soto Lopez,' Marcia M De \\ Carvalho, Delaine Meireles Gouvêa,' Laís \\ Silva Batalha,' Isabelle Oliveira Neves,' \\ Regina C Santos Mendonça' \\ 'Universidade Federal de Viçosa, Departamento de Tecnologia \\ de Alimentos, Brazil \\ ${ }^{2}$ Instituto Federal Sudeste de Minas- Campus Barbacena, Brazil
}

Correspondence: Maryoris E Soto Lopez, Universidade Federal de Viçosa - Departamento de Tecnologia de Alimentos, Avenida Peter Henry Rolfs S/N.Viçosa, Minas Gerais- Brazil, CEP 36570-000, Tel +55 31 3899 380 I, Fax +55 31 38992227 , Email dramicrocta@hotmail.com

Received: October 24, 2015 | Published: November 02, 2015

\section{Introduction}

Almost every day, many foods are contaminated with pathogen bacteria that demand the use of efficient technology in food industry for consumer safety. Spoilage bacteria cause high losses in food industry and contribute for deteriorating consumer health. ${ }^{1}$ Therefore, it is necessary to use strict control measures against pathogens and spoilage bacteria.

Pseudomonas spp are aerobic, non-spore-forming, gram-negative, rod-shaped bacteria. Psychrotrophic pseudomonas are recognized as major spoilage microorganisms based on their extracellular enzymes. The enzymes are generally good indicator of the keeping quality of protein and lipid-rich foods. Although microbial spoilage may merely lead to foodstuffs being rendered unpalatable, it can also result in serious and even fatal illness. These microorganisms are a big problem for the food industry, mainly the poultry industry. The $P$. fluorescens group frequently causes the spoilage of dairy products. It is also important in patients with burns and cystic fibrosis. $P$. aeruginosa causes spoilage of foods and is pathogenic for humans and animals, often as a secondary infection. It is now recognized as a common source of many community acquired and nosocomial infections, and affects primarily immune-compromised people and those suffering from cystic fibrosis. The most common infections involve the cornea, skin, urinary tract, and respiratory tract, although infections may occur in essentially all anatomical locations. ${ }^{2-4}$ Rapid increase of antibiotic resistance in the bacterial community is an ecological phenomenon, but is also one of the greatest hazards for human and veterinary medicine worldwide. Circulation of antibioticresistant bacteria occurs mainly between four ecosystems (humans, animals, soils and aquatic environments) interconnected by water. ${ }^{5}$ Many aerobic pseudomonas are resistant to several antibacterial agents. This subject is of particular medical importance because members of this group, such as $P$. aeruginosa, are serious opportunistic human pathogens. The effective antimicrobial agents for the treatment of $P$. aeruginosa infections include some $\beta$-lactams, such as carbenicillin, ticarcillin, third-generation cephalosporins, the synthetic monocyclic $\beta$-lactam aztreonam, carbapenems, the aminoglycosides, and the quinolones. P. aeruginosa and other Pseudomonas fluorescens species are in general resistant to $\beta$-lactams. ${ }^{3,5-7}$

These facts, making necessary novel and most effective approaches for treat infections caused by multidrug-resistant bacteria. In this context, bacteriophages suggest be a potential tool for treated this type of bacteria due to ability for infect and kill bacteria. ${ }^{8}$ This tool, was a useful practice before the advent of antibiotics, but in nowadays the antimicrobial resistance is increasing and require others strategies to combat. Bacteriophages are considered the most abundant organisms on the planet. It is estimated that the number of phages on the planet are higher than $10^{30}$ viral particles. ${ }^{9,10}$ Phages are considered ubiquitous agents. ${ }^{8}, 10$ Like all virus, phages do not have intrinsic metabolism and depend on metabolic machinery of host bacteria for replication. From one bacterium, almost 100 new viral particles can be released, all capable of infecting new bacteria. So, the infection cycles have potential to remain until all bacteria are dead. ${ }^{4}$ Even creating a resistance to a particular phage, bacteria is susceptible to other with similar hosts. Therefore, they can be biocontrol agents in food, and a great tool against resistance to antibiotics. ${ }^{11,12}$ The use of bacteriophages to control pathogens is promising and is becoming a reality. Although the practice of primary bacteriophage therapy has 
been performed with a view to the treatment of bacterial infections in humans, the concept of removing undesirable bacterial populations using bacteriophages can be extended to animals, plants, foodstuffs and other domains. ${ }^{13}$ Considering that bacteria are becoming increasingly resistant to antimicrobials, the present work aimed to isolate and characterize lytic bacteriophage for Pseudomonas spp as a potential alternative for decontamination of food products, mainly poultry products.

\section{Materials and methods}

\section{Organisms and growth conditions}

The host bacterial strains for phage isolates were $P$. aeruginosa (ATCC 25619) and P. fluorescens (ATCC 13525). The phages were isolated according to the adapted methodology of Sambrook et al., ${ }^{14}$ and Atterbury et al., ${ }^{15}$ from 11 samples of frozen chicken carcasses, in 15 slaughterhouses in Minas Gerais state in Brazil. Stock cultures were maintained frozen at $-20^{\circ} \mathrm{C}$. Pseudomonas grew in optimal conditions $\left(30^{\circ} \mathrm{C} / 24 \mathrm{~h}\right)$ in Brain Heart Infusion medium (BHI-Himedia, Mumbai, India). Pseudomonas had previously been characterized as resistant to amoxicillin, nalidixic acid, meropenem, trimethoprim and aztreonam (SOTO et al, unpublished data). Table 1 showed other bacterial strains used to evaluate the host range of isolated bacteriophages. All bacteria were subcultures placed on $\mathrm{BHI}$ agar plates at optimal temperature for $24 \mathrm{~h}$.

\section{Bacteriophage isolation and purification}

The bacteriophages were isolated from chicken frozen carcasses collected from 15 different slaughterhouses located in Minas Gerais state. $10 \mathrm{~mL}$ of each sample (chicken defrosted carcasses) were diluted at the proportion of 1:1 in SM buffer (Magnesium sulfate: 50 mmoles. $\mathrm{g}^{-1}$ Tris- $\mathrm{HCl}$ (Sigma) [pH 7.5], 0.1 moles. $\mathrm{g}^{-1} \mathrm{NaCl}$ (Merck), 8 mmoles. ${ }^{-1} \mathrm{MgSO}_{4} \cdot 7 \mathrm{H}_{2} \mathrm{O}$ (Chemco), $0.01 \%$ gelatin (Difco ${ }^{\mathrm{TM}}$ ) with agitation during 5 minutes.

The suspension was incubated in shaker (Braun-Biotech International) to $150 \mathrm{rpm}, 17^{\circ} \mathrm{C} / 24 \mathrm{~h}$ so as to allow phage migration to buffer. After incubation time, $8 \mathrm{~mL}$ was transferred to the centrifugation tube and $1 \mathrm{~mol} \cdot \mathrm{g}^{-1} \mathrm{NaCl}$ was added in standby for 15 minutes. Subsequently, it was supplemented with chloroform (Isofar) and the sample was refrigerated for 30 minutes. Finally, the sample was centrifuged to $4.000 \mathrm{~g} / 20 \mathrm{~min} / 4^{\circ} \mathrm{C}$ and the supernatant was collected. Each phage isolate was subjected to a minimum of three successive rounds of serial plaque purification and final lysates were stored in SM buffer at $4^{\circ} \mathrm{C}$ for further use.

\section{Phage presence determination}

To determine if the isolate procedure was correctly performed, it was used the droplet surface technique modified by Hungaro et al. ${ }^{16}$ The bacterial strains ATCC 25613 and ATCC 13525 were previously activated in TSB (Trypticase Soy Broth-Himedia) $30^{\circ} \mathrm{C} / 24 \mathrm{~h}$. After incubation, each suspension was adjusted to $10^{8} \mathrm{UFC} / \mathrm{mL}$ (D.O:1.0/600nm) in a spectrophotometer (Bioespectro-SP22).

In $5 \mathrm{~mL}$ of TSA semi-solid agar $(0.7 \%$ bacteriological agar $/ 100 \mathrm{~mL}$ TSB), it was added $0,5 \mathrm{~mL}$ of each bacteria, which were added over a petri plate containing TSA (Trypticase Soy Agar-Himedia). After solidification, micro-droplets $(0,1 \mathrm{~mL})$ of each phage suspension were deposited over the surface plate. The plates were incubated for 18 $24 \mathrm{~h} / 30^{\circ} \mathrm{C}$.

\section{Phage purification and propagation}

Phages were purified according to Sambrook et al. ${ }^{14}$ methodology, by adding concentrated phage suspension $(0.3 \mathrm{~mL})$ to bacterial strains $(0.2 \mathrm{~mL} / \mathrm{DO}: 0.5-600 \mathrm{~nm})$. Then, they were incubated at $30^{\circ} \mathrm{C} / 30$ minutes. Later, the suspension was added to TSA semi-solid agar and the set was supplemented over petri plates containing TSA. The plates were incubated at $30^{\circ} \mathrm{C} / 24 \mathrm{~h}$. After incubation time, isolated lysis plates were identified, one was cut and transferred to a tube with bacterial culture (DO:0.5/600nm) and incubated again for $24 \mathrm{~h} / 30^{\circ} \mathrm{C}$. Next, it was added $1 \mathrm{~mol} / \mathrm{g} \mathrm{NaCl}$ with standby for 15 minutes. Later, it was supplemented with $10 \%$ of chloroform (total volume) and the sample was incubated at $4{ }^{\circ} \mathrm{C} / 30$ minutes. Finally, the resulting suspension was centrifuged $\left(4.000 \mathrm{~g} / 20 \mathrm{~min} / 4^{\circ} \mathrm{C}\right)$ and the supernatant was recovered and stored at $4^{\circ} \mathrm{C}$.

\section{Phage quantification}

Phage stocks were serially diluted in SM buffer to achieve a concentration that would provide individual lysis plaques in a bacterial lawn. Aliquots $(100 \mu \mathrm{L})$ of diluted phage solution, $100 \mu \mathrm{L}$ of a bacterial overnight culture (DO:0.5/600nm), and $3 \mathrm{~mL}$ of semisolid TSA agar were mixed and poured onto TSA agar plates. The plates were incubated overnight at $30^{\circ} \mathrm{C}$ and the number of plaques was counted on the appropriate dilutions, providing between 10 and 100plaques.

\section{Phage morphologic characterization}

The bacteriophage morphology exam was performed as described by Sambrook et al. ${ }^{14}$ Phage suspension $(0.1 \mathrm{~mL})$ and $10 \%$ of PEG 8000 (Sigma) were transferred to a microtube. The mixture was maintained under refrigeration for $14 \mathrm{~h}$ and later centrifuged $\left(11.000 \mathrm{~g} / 20 \mathrm{~min} / 4^{\circ} \mathrm{C}\right)$. The supernatant was discarded and the pellet was resuspended in $1 \mathrm{~mL}$ of SM buffer and incubated for $1 \mathrm{~h} / 24^{\circ} \mathrm{C}$. Then, chloroform $(1 \mathrm{~mL})$ was added and homogenized. The suspension was centrifuged $\left(3.000 \mathrm{~g} / 15 \mathrm{~min} / 4^{\circ} \mathrm{C}\right)$ and the supernatant was recovered. $0,8 \mathrm{~mL}$ of supernatant was deposited on the transmission electron microscopy (TEM) film provided with carbon-coated Formvar (Koch), stained with $2 \%$ uranyl acetate (Sigma-Aldrich, Saint Louis, USA), rinsed with distilled water and allowed to dry for $24 \mathrm{~h}$. After drying, was examined in a Zeiss EM109 transmission electron microscope (performed by Microscope Center, Universidade Federal de Viçosa, Brazil).

\section{Phage lytic spectrum}

The host range of each phage was determined against 15 bacterial strains (Table 1). The susceptibility of various bacterial strains was tested using the drop-on-lawn technique. ${ }^{16}$ Aliquots $(10 \mu \mathrm{L})$ of serial dilutions of the different phage suspensions were added to bacterial culture. The plates were incubated overnight under optimal condition for each strain, and the lytic activity was checked for the formation of clear areas and phage plaque formation on the bacterial carpet. Each microorganism was incubated at the optimal growth temperature.

\section{DNA extraction and Restriction Fragment Length Polymorphism (RFLP)}

Purified phage suspensions were previously treated for 10minutes with chloroform 50\% (Carlo Erba, Italia) and centrifuged $(10.000 \mathrm{xg} / 20 \mathrm{~min})$. The supernatant was treated with DNase I (Sigma-Aldrich) and RNAse A $(1 \mu \mathrm{g} / \mathrm{mL})$ to disrupt bacterial DNA 
and RNA. Capsids were disintegrated using proteinase K (SigmaAldrich), isopropanol (Vetec) and sodium dodecyl sulfate-SDS (10\%) (LCG Biotecnologia). Phages DNA were extracted by the phenol/ chloroform method and precipitated by standard ethanol (70\%-Vetec) procedure. Phage DNA were extracted using the adapted protocol of Sambrook et al. ${ }^{14}$

The DNA was digested with HaeIII, Hinfl and AluI (Promega) following the manufacturer's recommendations. The DNA extracted was quantified by use of quantity markers $\lambda \mathrm{DNA}(25,50$ and $100 \mathrm{ng})$ and running in agarose gel (1.2\%) (Invitrogen). For RFLP, it was used DNA molecular marker (1Kb-Promega) and agarose gel (1.5\%). The obtained fragments were visualized after electrophoresis and illumination by UV light (Vilbert Lourmat).

\section{Results and discussions}

\section{Phage isolation, purification, propagation and quantification}

Eleven bacteriophages were isolated and purified successfully from product of chicken carcasses defrost with bacterial culture tested (Figure 1). Initially, these phages were isolated based on their ability to lyse $P$. aeruginosa (ATCC 25619) (phages assigned asPa1 to Pa10) and P. fluorescens (ATCC 13525) (Pa11). The specificity was identified after incubation for $24 \mathrm{~h} / 30^{\circ} \mathrm{C}$.

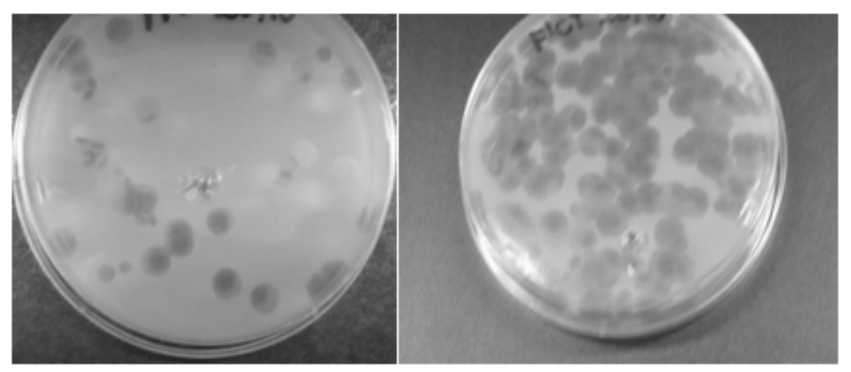

Figure I Lysis plaques caused by phages isolated from defrost chicken carcass exudate. That lysis evidenced phage action onto $P$. aeruginosa and $P$. fluorescens.

The exudate of chicken was an excellent source for phage isolation for these strains, and phage specific for Pseudomonas could be isolated from other sources, such as water, wastewater, feces, soil, and others, provided that a host is present. ${ }^{17,18}$ During propagation, phages proved capable of replication and achieved concentrations of up to $10^{11} \mathrm{UFP} / \mathrm{mL}$. Hungaro et al. ${ }^{16}$ observed that bacteriophages in high concentration (near to $10^{9} \mathrm{PFU} / \mathrm{mL}$ ) are necessary for optimum efficacy of phage, however, concentrations equal or less than $10^{6} \mathrm{PFU} /$ $\mathrm{mL}$ were not able to reduce growth of $S$. Enteritidis in chicken carcasses. So, our bacteriophages for Pseudomonas can be propagated easily and reach high concentrations, this feature, can be considered another advantage for potential use in the food industry.

\section{Phage morphological characterization}

Electron transmission microscopy evidenced that the phages isolated in this work can be classified into the Caudovirales order but in different families. All phages showed size approximate of $200 \mathrm{~nm}$. Figure 2 showed the typical morphology of phages, the object of this study. Specific phages for $P$. aeruginosa were included into the Podoviridae family. These phages are characterized by icosahedral heads, dsDNA and non-contractile tail. ${ }^{10}$

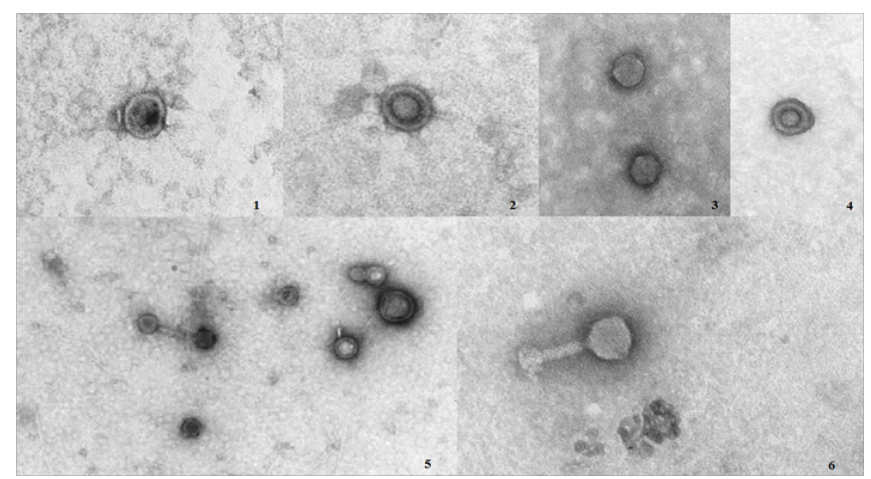

Figure 2 photomicrographs of bacteriophages: 1) $\mathrm{Pa} 3$, 2) $\mathrm{Pa}$ 5, 3) $\mathrm{Pa}$ 7, 4) $\mathrm{Pa} 8$, 5) PaI0 and 6) Pal I, visualized in TEM (8.500X)

On the other hand, Pa11 phage with specificity for P. fluorescens was included into the Myoviridae family, presented contractile neck ${ }^{10}$ and dsDNA. Although having similar morphology, the genetic profile of phages is not obligatorily similar, because the environment of isolation is different and faraway. According to Garbe et al. ${ }^{19} 499$ bacteriophages have been described particularly for Pseudomonas, out of which 139 belong to the Myoviridae family. Kumari et al., ${ }^{18}$ Sepulveda-Robles et al. ${ }^{20} \&$ Sillankorva et al..$^{21}$ found similar results for isolated bacteriophages for P. aeruginosa and P. fluorescens.

\section{Lytic spectrum}

Table 1 exhibited phage activity propagated into $P$. aeruginosa and $P$. fluorescens. This analysis is related to phage action on different strains of importance for human and animal health. PA11 phage showed specificity in many bacteria such as $S$. Enteritidis, $K$. pneumoniae, $S$. Typhimurium, $S$. Choleraesuis, E. coli, P. aeruginosa, $P$. Fluorescens, P. putida and E. aerogenes and almost all these microorganism represented some problem for food industry. Other phage that showed an interesting profile was PA6. Due to action spectrum, these bacteriophages can be interesting candidates for use in biosanitization and phage therapy in food industry. Some phages specific from bacteria belonging to the Enterobacteriacea family were capable of infecting other strains..$^{22,23}$

The similarity between the compositions of bacterial wall surface of Gram negative bacteria that serve as receptors for bacteriophage ligations can have influence in these results. These bacteriophages were not specific against to Gram positive bacteria tested. Phages with capacity to infect several hosts included different genus of microorganism exhibit potential of use in control and therapy of foodborne pathogens. This characteristic avoids simplification and reduces production costs of phage suspension, also increasing the safety margin, meanwhile the phage used against pathogens could be replicating in non-pathogen bacteria. ${ }^{23}$

Physical, chemical and biological methods have been studied and applied on food chain to reduce food borne pathogens and spoilage bacteria, especially in the poultry industry. Bacteriophages can be studied and coupled with these methods to improve microbiological safety in food industry. To increase the potential efficiency of this antimicrobial alternative, a mix of phages is an option that could contribute to combat several pathogens and antimicrobial resistance. 
Table I Evaluation of lytic spectrum of isolated bacteriophages with Pseudomonas aeruginosa and Pseudomonas fluorescens as host, in relation with others bacteria

\begin{tabular}{|c|c|c|c|c|c|c|c|c|c|c|c|}
\hline \multirow[t]{2}{*}{ Microorganism } & \multicolumn{11}{|c|}{ Bacteriophages } \\
\hline & Pa1 & $\mathbf{P a 2}$ & Pa3 & Pa4 & Pa5 & Pa6 & $\mathbf{P a} 7$ & $\mathrm{~Pa} 8$ & Pa9 & Pa10 & Pa11 \\
\hline Salmonella Enteritidis ATCC13076 & + & + & + & + & + & + & + & + & + & + & + \\
\hline Klebsiella pneumoniae ATCC10031 & + & + & + & + & + & + & + & + & + & + & + \\
\hline Salmonella Typhimurium ATCC14028 & + & + & + & + & + & + & + & + & + & + & + \\
\hline Salmonella Pullorum ATCC9120 & - & - & - & - & - & - & - & - & - & - & - \\
\hline Salmonella Choleraesuis ATCC10708 & - & - & - & - & - & - & - & - & - & - & + \\
\hline Salmonella Abony ATCC6071 & - & - & - & - & - & - & - & - & - & - & - \\
\hline S.arizonae & - & - & - & - & - & - & - & - & - & - & - \\
\hline \multicolumn{12}{|l|}{ ATCC13314 } \\
\hline Escherichia coli ATCC11229 & - & - & - & - & - & - & + & - & - & - & + \\
\hline S. aureus & - & - & - & - & - & - & - & - & - & - & - \\
\hline \multicolumn{12}{|l|}{ ATCC 13565} \\
\hline S. aureus & - & - & - & - & - & - & - & - & - & - & - \\
\hline \multicolumn{12}{|l|}{ ATCC6538 } \\
\hline P. aeruginosa ATCC25619 & + & + & + & + & + & + & + & + & + & + & + \\
\hline P. Fluorescens ATCC 13525 & - & - & - & - & - & - & - & - & - & - & + \\
\hline P. putida & - & - & - & - & - & - & - & - & - & - & + \\
\hline \multicolumn{12}{|l|}{ ATCC 15145} \\
\hline Enterobacter aerogenes ATCC13048 & - & - & - & - & - & - & - & - & - & - & + \\
\hline
\end{tabular}

(+) Positive lysis; (-) Negative lysis

\section{Genetic profile of bacteriophages}

The DNA extracted showed concentration of approximately $50 \mathrm{ng}$ of $\lambda \mathrm{DNA}$ marker. It was possible to identify that 5 isolated bacteriophages had different restriction profiles, according to RFLP. The RFLP detected with HaeIII enzyme allowed differentiating phages $\mathrm{Pa} 3, \mathrm{~Pa} 7, \mathrm{~Pa} 8, \mathrm{~Pa} 10$ and $\mathrm{Pa} 11$. It suggests that isolated phages have different genetic profiles (Figure 3 ) although of their very similar morphology. The other restriction enzymes tested do not showed fragmentation on bacteriophages DNA, clearly.

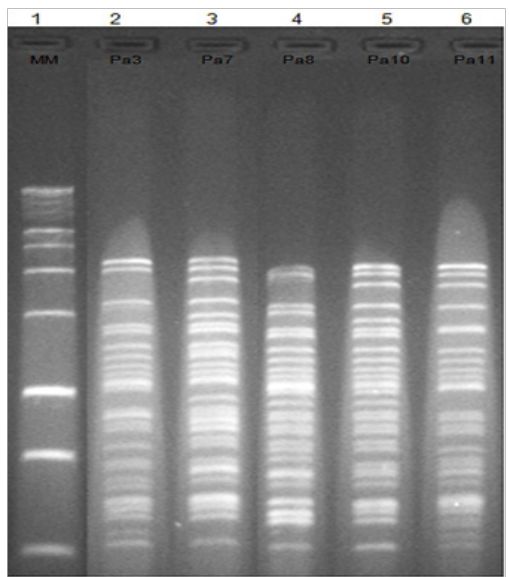

Figure 3 Patterns of digestion with restriction endonucleases Haelll of DNA isolated phages. Column I: molecular marker (I Kb); Column 2-6: DNA phages: $\mathrm{Pa} 3, \mathrm{~Pa} 7, \mathrm{~Pa} 8, \mathrm{~Pa} 10$ and Pall respectively, digested with Haell enzyme.
Knezevic et al. ${ }^{24}$ identified and characterized bacteriophages for $P$. aeruginosa. Based on RFLP profile with EcoRI, EcoRV and BamHI enzymes, they concluded that their phages were genetically different. Seven phages used in this study presented similar morphology and its restriction digest profiles were indistinguishable from each other. Also, there were not evident differences between of these phages, their replication dynamics and host range. Sequencing is required to complete identification, although the morphological and genetic characterization of these phages suggests that they belong to identical phage-types.

\section{Conclusion}

In the present work, it was observed that phages can be isolated of industrial foods. Bacteriophage PA11 have a big potential for use in food industry as indicate or as control foodborne pathogens and spoilage bacteria, due to their large spectrum of action and their high concentration achieved. The fact of isolated phages of Pseudomonas has a large specificity represent a big advantage and we believe that bacteriophage-based treatment can be applied for pathogen control in poultry carcasses and others industrial products. However, studies are necessary to know the behavior of bacteriophage in food industry for future applications.

\section{Acknowledgements}

The research group thanked the Núcleo de Microscopiae Microanálisis of University of Viçosa-Minas Gerais, Brazil for their help in the determination of phage morphology. 


\section{Conflict of interest}

The author declares no conflict of interest.

\section{References}

1. Bassett KD. Use of bacteriophage as an antimicrobial in food products Manhattan, $57 \mathrm{f}$ Tesis (Magister en Ciencias)- Colegio de agricultura. Manhattan, USA: Kansas State University; 2007.

2. Mantilla SPS, Santos ÉB, Júnior CAC, et al. Bactérias deteriorantes em filés de frango embalados em ar, vácuo e irradiados: parâmetros bacteriológicos de desenvolvimento e prazo comercial. Pesquisa Agropecuária Tropical. 2009;39(4):271-277.

3. Arslan S, Eyi A, Özdemir F. Spoilage potentials and antimicrobial resistance of Pseudomonas spp. isolated from cheeses. J Dairy Sci. 2011;94(12):5851-5856

4. Centers for Disease Control and Prevention (CDC). Antibiotic Resistance Threats in the United States; 2013.

5. Flores Ribeiro A, Bodilis J, Alonso L, et al. Occurrence of multiantibiotic resistant Pseudomonas spp. in drinking water produced from karstichydrosystems. Sci Total Environ. 2014;490:370-378.

6. Garrity GM, Bell JA, Lilburn T. Phylum XIV. Proteobacteria phyl. nov. In: Garrity GM, et al. Editors. Bergey's Manual of Systematic Bacteriology. 2nd ed. Volume 2, Part B. New York, USA: Springer; 2005. 1 p.

7. Carlos Juan Nicolau Y, Antonio Oliver. Carbapene masas en especies del género Pseudomonas. Enferm Infecc Microbiol Clin. 2010;28(Supl 1):19 28.

8. Hanlon GW. Bacteriophage: an appraisal of their role in treatment of bacterial infections. Int J Antimicrob Agents. 2007;30(2):118-128.

9. Hendrix RW, Smith MC, Burns RN, et al. Evolutionary relationships among diverse bacteriophages and prophages: All the world's a phage Proc Natl Acad Sci India Sect B Biol Sci. 1999;96(5):2192-2197.

10. Hungaro HM, Lopez MES, Albino LAA, et al. Bacteriophage: The viruses infecting bacteria and their multiple applications. In: Reference Module in Earth Systems and Environmental Sciences. USA: Elsevier; 2014.

11. Sulakvelidze A, Alavidze Z, Morris JG Jr. Bacteriphagetherapy. Antimicrob Agents Chemother. 2001;45(3):649-659.

12. García P, Madera C, Martínez B, et al. Biocontrol of Staphylococcus aureus in curd manufacturing processes using bacteriophages. Int Dairy J. 2007;17(10):1232-1239.
13. Gill JJ, Young RF. Therapeutic applications of phage biology: history, practice and recommendations. In: Miller AA, et al. editors. Emerging Trends in Antibacterial Discovery: Answering the Call to Arms. UK: Caister Academic Press; 2011. 460 p.

14. Sambrook J, Russel DW. Molecular Cloning: a Laboratory Manual. 3rd ed. USA: Cold Spring Harbor Laboratory Press; 2001.

15. Atterbury RJ, Dillon E, Swift C, et al. Correlation of Campylobacter bacteriophage with reduced presence of hosts in broiler chicken ceca. Appl Environ Microbiol. 2005;71(8):4885-4887.

16. Hungaro HM, Mendonça RCS, Gouvêa DM, et al. Use of bacteriophages to reduce Salmonella in chicken skin in comparison with chemical agents. Food Res Int. 2013;52(1):75-81.

17. Budzik JM. Phage Isolation and Investigation. Dartmouth Undergraduate Journal of Science. 2000;3(1):37-43.

18. Kumari S, Harjai K, Chhibber S. Characterization of Pseudomonas aeruginosa PAO Specific Bacteriophages Isolated from Sewage Samples. Am J Biomed Sci. 2009;1(2):91-102.

19. Garbe J, Bunk B, Rohde M, et al. Sequencing and Characterization of Pseudomonas aeruginosa phage JG004. BMC Microbiol. 2011;11:102.

20. Sepúlveda-Robles O, Kameyama L, Guarneros G. High diversity and novel species of Pseudomonas aeruginosa bacteriophages. Appl Environ Microbiol. 2012;78(12):4510-4515.

21. Sillankorva S, Neubauer P, Azeredo J. Phage control of dual species biofilms of Pseudomonas fluorescens and Staphylococcus lentus. Biofouling. 2010;26(5):567-575.

22. O'Flynn G, Ross RP, Fitzgerald GF, et al. Evaluation of a cocktail of three bacteriophages for biocontrol of Escherichia coli O157:H7. Appl Environ Microbiol. 2004;70(6):3417-3421.

23. Bielke LR, Higgins SE, Donoghue AM, et al. Use of wide-host-range bacteriophages to reduce Salmonella on poultry products. International Journal of Poultry Science. 2007;6(10):754-757.

24. Knezevic P, Kostanjsek R, Obreht D, et al. Isolation of Pseudomonas aeruginosa specific bacteriophages with broad activity spectra. Curr Microbiol. 2009;59(2):173-180. 